Article

\title{
Love and Do What You Want: Augustine's Pneumatological Love Ethics
}

\author{
Mac S. Sandlin
}

check for

updates

Citation: Sandlin, Mac S. 2021. Love and Do What You Want: Augustine's Pneumatological Love Ethics. Religions 12: 585. https://doi.org/ 10.3390/rel12080585

Academic Editors: J. Caleb Clanton and Kraig Martin

Received: 14 June 2021

Accepted: 23 July 2021

Published: 29 July 2021

Publisher's Note: MDPI stays neutral with regard to jurisdictional claims in published maps and institutional affiliations.

Copyright: (C) 2021 by the author. Licensee MDPI, Basel, Switzerland. This article is an open access article distributed under the terms and conditions of the Creative Commons Attribution (CC BY) license (https:/ / creativecommons.org/licenses/by/ $4.0 /)$.
Department of Doctrine and History, Harding University, Searcy, AR 72143, USA; mssandlin@harding.edu

\begin{abstract}
Augustine famously summarizes all of ethics in the maxim, "Love and do what you want" in his Homilies on the First Epistle of John, but also describes sin as misdirected love and humanity as characterized by sin. This raises the question as to how Augustine can offer such a maxim given humanity's tendency to love so poorly. Aimed at ethicists and theologians with only a general knowledge of Augustine, this paper examines Augustine's approach to ethics and its relationship to his theology of the Holy Spirit. By exploring the ordo amoris, the uti/frui distinction, and the doctrine of the Spirit as the inner-Trinitarian Love of the Father and the Son, I attempt to show how Augustine's maxim can fit with his hamartiology.
\end{abstract}

Keywords: Augustine; pneumatology; ethics; love; virtue; divine command; holy spirit

"... though every inclination of man's heart is evil from childhood". (Gen 8:21)

"You shall love the Lord your God with all your heart and with all your soul and with all your mind. This is the great and first commandment. And a second is like it: You shall love your neighbor as yourself. On these two commandments depend all the Law and the Prophets". (Mt. 22:35-40)

"The love of God has been poured into our hearts by the Holy Spirit who has been given to us". (Rom. 5:5)

"Beloved, let us love one another, for love is from God, and whoever loves has been born of God and knows God. Anyone who does not love does not know God, because God is love". (1 Jn. 4:7-8)

\section{Introduction}

Augustine was as aware of his own sinfulness as perhaps anyone who has ever lived. He imparted to the West the doctrine of original sin and the groundwork for later Calvinistic notions of total depravity. He tells the story of his life as a series of confessions to God, and he invites his readers to join him in contemplating the manifold wickedness of his own sinfulness. "Woe, woe, by what steps I was dragged down to the depths of Hell' - toiling and fuming because of my lack of the truth, even when I was seeking after thee, my God!"' Even after his conversion and years of service as a bishop and theologian, when his last illness came, Augustine chose to meet death alone, lying in bed and reading the penitential Psalms while weeping over his sins. ${ }^{2}$

Despite what one might think in light of such a strong interest in guilt and sinfulness, Augustine was not a man plagued by insecurity and self-loathing, not one who thought his sins were especially wicked. Rather, he saw himself as he saw all humanity-broken and in need of repair, lost and in need of salvation. In his descriptions of his own sin, we see his view of sin and human sinfulness in general. ${ }^{3}$

Human sinfulness, Augustine believed, resulted from misdirected or disordered love, making a sharp distinction between that which we ought to use and that which we ought to enjoy. ${ }^{4}$ Sin comes from enjoying that which ought to be used and thereby becoming entangled in disordered loves. Given the ease with which humanity falls into this trap of 
loving the wrong thing or loving in the wrong way, one might expect Augustinian ethics to take the form of a theory in which right is named and judged by static external rules grounded in eternity rather than arising from individual conscience or social norms - divine command theory or some sort of legalism perhaps. And so, it is surprising to find the same man who teaches us that sinfulness results from our misdirected loves summing up his entire ethical thought in these five short words: dilige, et quod vis fac- "Love, and do what you want (Augustine 2008 ${ }^{5}$ )" How can Augustine, who believes that humanity is so sinful and that $\sin$ is disordered love, advise us to "love and do what you want" without abandoning either his view of sin and human sinfulness? When one loves rightly, right actions will result, but how are we to rightly order our loves? By what means will our loves be transformed? The answer lies not in Augustine's anthropology but in his Pneumatology, for the good is not a merely a principle or a power for Augustine; it is the living person of the Holy Spirit. This Pneumatological love ethic helps unite his moral and theological doctrines and provides important clarification for some of Augustine's more controversial ethical positions as well as correctives and helpful direction for contemporary virtue ethics.

This article will therefore offer an overview of the Augustine's ethica caritatis as a moral theory and then examine his doctrine of the Holy Spirit as the divine love of God and the implications of such a doctrine for his moral theology. The first section will outline the basic shape of Augustine's ethica cartiatis. It concludes with a discussion of why it is difficult to fit Augustine into any of the major ethical systems embraced by his intellectual heirs and students. The major primary sources engaged in part one include On the Moral Teaching of the Catholic Church, City of God, and Teaching Christianity. The second section looks at Augustine's trinitarian and Pneumatological theology and the importance of caritas in Augustine's thinking about God. It draws primarily from On the Trinity. Woven throughout both sections of the paper and uniting them are Augustine's Homilies on First John, the source from which our driving question comes and also where it finds its answer. I conclude with a brief discussion of implications of Augustine's Pneumatological love ethics for further research in theology proper and theological ethics.

My goal in this article is not to uncover new insights in Augustinian theology or ethics, but to show the connection between Augustine's Pneumatology and his ethics which may not be obvious to non-experts, especially those from traditions like my own (Churches of Christ, Stone-Campbell Movement) in which Augustine and his famous maxim, "Love and do what you want" are viewed with suspicion and hostility. To explore either Augustine's doctrine of the Spirit or his approach to ethics fully is clearly beyond the scope of this article, but I hope that breadth and consequent lack of depth of my topic is appropriate for a special issue such as this one.

\section{Augustine's Ethica Caritatis}

If the early church fathers had been asked for a scriptural summary of Christian ethics, they would likely have pointed to the Sermon on the Mount. ${ }^{6}$ This was among the most-quoted and most referenced passage of Scripture in the writings of the early church, and the patristic commentary tended to emphasize themes like obedience, visible action, and radical counter-cultural witness. ${ }^{7}$ With Augustine, the emphasis shifts from Matthew 5-7 to Matthew 22, from the Sermon on the Mount to the Greatest Commands. ${ }^{8}$ O'Donovan notes, "It is surprising how little attention is paid to the 'summary of the law,' the 'two commands,' of love-of-God and love-of-neighbor, in either the Western or the Eastern Fathers [before Augustine]." ${ }^{\prime 9}$ Augustine, he argues, is responsible for the place of primacy the 'summary' takes on in Western Christian ethics. For generations, it displaced or reinterpreted not only the earlier emphasis on counter-cultural witness but also the standard philosophical approaches to ethics.

This emphasis on love is discernable in Augustine's work from the beginning. His treatise, On the Moral Teaching of the Catholic Church (De Moribus) is an early work written against the Manichees. In it, Augustine follows a traditional philosophical line of questioning as he seeks to identify humanity's chief good and to determine how this summum bonum 
might be apprehended. However, De Moribus is stridently anti-philosophical in its rhetoric. Augustine's answers are explicitly theological and biblical rather than philosophical, so it is not surprising that in that work he identifies the summum bonum as God. "The perfection of all our good things and our perfect good is God. We must neither come short of this nor go beyond it: the one is dangerous, the other impossible."10 The way to apprehend this highest good, he asserts, is by love.

What exactly Augustine means by love is not always clear, but some generalizations can still be made: (1) Love always involves the will. (2) There is a hierarchy of value among things that are to be loved, an "ordo amorum" with God at the top, other human beings in the middle, and non-human things at the bottom. (3) Love can be misdirected or disordered and this distortion results in sin.

\subsection{Love and the Will}

Phillip Cary argues that Augustine invents the concept of the will and bequeaths it to all of later Western philosophy. ${ }^{11}$ Augustine's doctrine of the will emerges from his exploration of the origin and nature of evil. Since evil for Augustine is not a thing with substance but rather a privation or perversion of goodness-a turning from the real and the good-it can only come about by the use of some power or cause which allows that turning to take place.

When the will abandons what is above itself, and turns to what is lower, it becomes evil—not because that is evil to which it turns, but because the turning itself is wicked. Therefore, it is not an inferior thing which has made the will evil, but it is itself which has become so by wickedly and inordinately desiring an inferior thing. ${ }^{12}$

This ability to turn, to act upon or move toward desire is the essence of love and therefore the essence of ethics for Augustine. Love and the will are tightly connected whether in sin or in righteousness. As Pratt notes, all sinfulness is a sinfulness of the will, but Augustine is also clear in The Spirit and Letter that God's grace makes us righteous precisely because it frees the will to love righteousness. ${ }^{13}$

\subsection{The Order of Loves}

The famous Augustinian doctrine of the order of loves (ordo amorum), teaches that things are to be loved according to their proper ordering. One key text for this doctrine is Matthew 22 with its discussion of the greatest commands.

Now God, our master, teaches two chief precepts, love of God [and] love of neighbor; and in them man finds three objects for his love: God, himself, and his neighbor; and a man who loves God is not wrong in loving himself. It follows, therefore, that he will be concerned also that his neighbor should love God, since he is told to love his neighbor as himself; and the same is true of his concern for his wife, his children, for the members of his household, and for all other men, so far as is possible. ${ }^{14}$

Augustine points out that the greatest commands teach us that there exists a hierarchy of loves and that having that hierarchy firmly in place is essential for any proper ethical act. If we love God properly, we will also love our neighbor and ourselves properly. As Chappell argues, "Character cannot be good without being truly aligned with the ordo amorum." 15 The existence of this hierarchy is key not only to Augustine's love-ethic but also to his closely-related doctrine of sin.

\subsection{Disordered Loves}

The misalignment of loves is at the heart of Augustine's notion of evil and of his hamartiological teaching as a whole. All sin is fundamentally a matter of misdirected or inordinate desire acted upon by the will, that is, by love. For love, in the Augustinian sense, can be defined as the direction of the will towards an object of desire. As Harvey puts 
it, "Morality consists in directing our liberty towards God."16 When people love created things as if they were eternal things, when they direct their will inappropriately toward creatures instead of toward God, when they allow themselves to be captivated by the things of the world rather than letting their restless hearts find rest in God, their true end, the result is sin, evil, judgment, and death.

This basic principle lies at the heart of all Augustinian theology, but it is perhaps most famously expressed in his aforementioned uti/frui distinction from On Christian Doctrine. There he writes that God alone is to be enjoyed (frui), and all else is to be used (uti).

Among all the things there are, therefore, those alone are to be enjoyed which we have noted as being eternal and unchanging, while the rest are to be used, in order that we may come at last to the enjoyment of the former sort. ${ }^{17}$

It is important to note, however, that Augustine does not use "enjoy" (frui) as a synonym for "love" (delectionis) in this passage. The question is not, "Ought we to love other people or love ourselves?" Scripture provides him with an obvious answer. The question, for Augustine, is, "How ought we to love ourselves and others?" or "We ought to love ourselves and others to what end?" And the answer he gives is that we ought to love others as a means to enjoying, resting, and finding our ultimate end in God. ${ }^{18}$ The metaphysical hierarchy represented in Augustine's uti/frui distinction therefore runs parallel to, but is not identical to the ordo amorum. Yet both doctrines manifest the underlying Augustinian principle that $\sin$ is rooted in the misdirected will of the individual who is led astray by his or her desire for that which is not or does not lead to God. In this, Augustine is thoroughly Johannine.

Do not love the world or the things in the world. If anyone loves the world, the love of the Father is not in him. For all that is in the world-the desires of the flesh and the desires of the eyes and pride of life-is not from the Father but is from the world. And the world is passing away along with its desires, but whoever does the will of God abides forever. (1 Jn. 2:15-17)

In a homily on this passage delivered around twenty years after his composition of $D e$ Doctrina, Augustine writes,

Why wouldn't I love what God has made? Maybe the Spirit of God be in you, so that you may see that all these things are good, but woe to you if you love created things and abandon the creator. They are beautiful as far as you are concerned, but how much more beautiful is he who formed them? . . . God doesn't forbid you to love those things, but you mustn't love them in the expectation of blessedness. Rather, you must favor and praise them in such a way that you love the creator. ${ }^{19}$

Augustine goes on to address the issue metaphorically with a parable in which a bride loves the wedding ring given to her by her bridegroom more than she loves the man himself. Clearly, says Augustine, such a woman possesses an adulterous heart insofar as she loves the gift more than she loves the one who made and gave the gift to her. He emphasizes that the world and the things in it are to be loved in appropriate ways, by which he simply means that they are not to be loved instead of or above God. Rather, it is in loving God that we see how to appropriately love the world. ${ }^{20}$

Not surely, that there is no allowed measure in these things [food, drink, and sex], or that when it is said, "Love not these things," it means that you are not to eat, or not to drink, or not to beget children? This is not the thing said. Only, let there be measure, because of the Creator, that these things may not bind you by your loving of them: lest you love that for enjoyment which you ought to have for use. But you are not put to the proof except when two things are propounded to you, this or that: Will you [choose] righteousness or gain? ${ }^{21}$

Here in the homilies Augustine's uti/frui distinction achieves its practical form-when faced with the choice, will you choose the things of the world over God? Will you direct 
your liberty towards them instead of towards God? Will you love God or something else? All ethics reduces to this one question for Augustine.

\section{God Is Love: Trinity and Pneumatology}

\subsection{God Is Love; The Spirit Is Love}

In De Trinitate, Augustine proposes a number of metaphors for the triune nature of God, but few are as consequential for his theology and his ethics as this one. "You see a trinity if you see love."22 Indeed, while he says early on that love is $a$ trinity, by the end of the work he has come to conclude that love is the Trinity and that all true loving (and if it is not true, he writes, it is not worthy of the name Love) is a participation in the triune life of God made possible by the gift of the Holy Spirit. ${ }^{23}$ Thus, he ends the first major section of De Trinitate with this observation:

Now love means someone loving and something loved with love. There you are with three, the lover, what is being loved, and love. And what is love but a kind of life coupling or trying to couple together two things, namely lover and what is being loved. ${ }^{24}$

And in the last book of the work he writes:

So God is charity. But the question is whether it is the Father or the Son or the Holy Spirit or the triad, because this triad is not three Gods but one God. ... I do not know why Father, Son, and Holy Spirit should not all be called charity and all together be one charity... In the same way the Father is God and the Son is God and the Holy Spirit is God, and they are all together one God. And yet it is not without point that in this triad only the Son is called the Word of God, and only the Holy Spirit is called the gift of God ... If therefore any of these three can be distinctly named charity, which could it more suitably be than the Holy Spirit. ${ }^{25}$

In his metaphor from book 8, the Father is the lover, the Son is the beloved, and the Spirit is the love which binds them together. We see here, even in the very nature of God, an ordo amorum at work. The Father is the originating principle and the son the begotten one, but the Spirit proceeds from and is directed towards both such that not only is the Son bound to Father, but the Father is also bound to the Son. So real equality and mutuality exists within the trinity without the loss of a discernable order of loves- "a truly self-giving reciprocal communion, not a hierarchy of powers." 26

Joseph Ratzinger points out that the Spirit is this reciprocity—-the communio between the Father and the Son. The Spirit's particular distinction is that he is that which the Father and the Son have in common, and this, Augustine argues, is evident even in the generic name "Holy Spirit" which he bears. ${ }^{27}$ The words "holy" and "spirit" are both applied to God generically and to the Father and the Son individually. These descriptors, "holy" and "spirit" are "the essential descriptions of God." Thus, Ratzinger argues, the Spirit for Augustine is the paradoxical mutuality of the Godhead. ${ }^{28}$ Such a view of the Spirit is tied up in the most controversial aspect of Augustinian trinitarian theology-the dual procession of the Spirit. While the Bishop of Hippo acknowledges that the Spirit precedes "principally" from the Father, it is vital to his doctrine of God that the Son also has "life in himself" (Jn. 5:26) from before all worlds and that this life which he receives from the Father by his eternal begetting is the Spirit which also proceeds from the Son back to the Father. ${ }^{29}$ It is this insight along with the identification of the Spirit with the divine gift which led Augustine to identify the Spirit as the love which unites the Father and the Son.

\subsection{The Spirit as Gift}

St. Hilary of Poitiers was the first to identify the Spirit as the Donum Dei, but Augustine expanded and improved upon Hilary's teaching. ${ }^{30}$ As is typical for most of Augustine's thinking about the Spirit, the Apostle John provided him with the key texts from Scripture. 
The story of the woman at the well in John 4 served as the primary reference for Augustine's Pneumatology. There Jesus tells the woman that his gift is greater than what he asked her to give, for the water he gives is living water, an expression that the Evangelist later explicitly identifies with the Spirit (Jn. 7:37). ${ }^{31}$ This identification of the Spirit with the gift of God allows Augustine to distinguish the Spirit from the Son while maintaining that both are "of God." 32 He makes the distinction most clearly in the following passage:

He [The Spirit] comes forth, you see, not as being born but as being given, and so he is not called Son because he was not born like the only begotten Son, nor made and born adoptively by grace like us. What was born of the Father is referred to the Father alone when he is called, and therefore he is the Father's Son and not ours too. But what has been given is referred both to him who gave and to those it was given to; and so the Holy Spirit is not only called the Spirit of the Father and the Son who gave him, but also our Spirit who received him. ${ }^{33}$

Thus, Augustine lays out three ways that persons have their origin in God (the Father): being begotten, being given, and being created. Of these, the first two are strictly the properties of divine persons and sharply distinguished from the broader category of created things. The two divine modes of origination are similar in that they are both rooted in eternity. The Son is eternally begotten of the Father and the Spirit is always given. God as Son and God as Gift are still fully God and remain fully unified with the Father, but both their mode or origination and their relationship to the Father are distinct. Just as the Son was begotten of the Father independent of his entry into human history via the virgin's womb, so also is the Spirit the Gift of God even before he brooded over the waters or moved the prophets to speak. For the Spirit is the Gift of the Father and the Son not only to creation, but also to each other. This mutual giving is foundational for Augustine's argument that the Spirit is the love of God.

\subsection{The Work of the Spirit: Binding, Teaching, Deifying}

What then does the Love of God poured out into our hearts do? A full answer is beyond the scope of this paper, but there are at least 3 elements of the Spirit's work that have a direct bearing on the Augustinian love ethic we are examining. First, the Spirit unites the Christian to God. Aquinas said, "Charity signifies not only the love of God, but also a certain friendship with Him." 34

If God is love, then we can be sure that he desires fellowship, friendship, and communion for their own sakes and that he implants that desire within his creatures. The Spirit unites both divine and human persons rendering the Christian one with God and with God's people. ${ }^{35}$

Ratzinger characterizes this work of forming deep communal bonds as "abiding." The Spirit abides with us and forms a stable relationship, one that mirrors the Spirit's presence in the life of Christ rather than in the figures of the Old Testament upon whom the Spirit would rush and empower only to depart until needed. ${ }^{36}$ Ratzinger identifies "abiding" as the basic criterion of love. "Love proves itself in constancy. [It] abides, overcomes vacillation, and bears eternity within itself." 37 And because love is characterized by abiding, it cannot take place anywhere except where there is eternity, that is, in God. Here we see the ultimate grounding for the ordo amorum. While contemporary notions of both love and the Spirit emphasize unpredictability and the tendency to break out of rules and institutions, Ratzinger points to constancy, loyalty, even the immutability as the fundamental characteristics of love, and he connects these characteristics to the Church.

The word caritas receives here [in Augustine's Pneumatology] a very concrete, ecclesiological meaning, and in fact, in Augustine's language it completely penetrates the concepts for he says that the Church is love... As a creation of the Spirit, the Church is the body of the Lord built up by the pneuma, and thus also becomes the body of Christ when the pneuma forms men and women for "communion." ... The dogmatic statement "The Church is love" is not merely a 
dogmatic statement for the manuals, but refers to the dynamism that forms unity, a dynamism that is the force holding the Church together. ${ }^{38}$

The notion of Spirit's work of binding Christians to God and to each other in an abiding fellowship of love is key for Augustine's Pneumatology and his ecclesiology, but it is also important for his ethics.

Second, as Jesus promised in John 14:26, the Spirit acts as teacher and guide for the Christian. ${ }^{39}$ Drawing on the Confessions, Harvey points to the importance of moral vision for Augustinian ethics and connects the development of this skill with the work of the Spirit. Conversion (itself a work of the Spirit and deeply associated with teaching), he reminds us is typically the result of the gradual process of gaining self-knowledge under the light of grace. And this is true for moral vision as well.

St. Augustine's concept of conscience is not purely philosophic but theocentric and dynamic. For him the judgments of conscience are not isolated phenomena, but complicated operations of the whole person in the varying situations of life-operations done under the influence of Divine Grace. ${ }^{40}$ This "theocentric dynamism" is the mark of the Spirit's activity. The knowledge of God and self does not come from a "dead letter" carved in stone for all ages, but from a living and intimately present tutor who instructs and corrects over time. Thus, Augustine writes, "That which I know of myself, I know by thy light shining upon me." ${ }^{41}$ For this Father of the Church, spiritual growth, including moral growth, is directly tied to self-knowledge, and self-knowledge comes exclusively from Divine illumination, a work explicitly associated with the Spirit's teaching role. ${ }^{42}$

Finally, the work of the Spirit is tied to Christian eschatology and the perfecting of God's people. Deification and its attendant themes of individual moral progress, the formation of a redeemed community, and the efficacy of the sacraments play a major role in Augustine's thought though it is one that has often been overlooked or denied outright. ${ }^{43}$ The work of theosis, the sanctifying deification of the Christian, begins in the present by the indwelling of the Spirit. We are "being transformed from one degree of glory to another for this comes from the Lord who is the Spirit" (2 Cor. 3:18) and are made "partakers of the divine nature" (2 Pt. 1:4). But Ratzinger notes that given that this is the work of the Spirit, we ought not to think of the divine nature or the increasing degrees of glory in terms of power and authority but in terms of love and fellowship with God and his people.

Becoming a Christian means becoming communion and thereby entering into the mode of being of the Holy Spirit. But it can also only happen through the Holy Spirit, who is the power of communication and is himself a Person. ${ }^{44}$

In all three of these major works associated with the Spirit, uniting, teaching, and perfecting, we see the tight connections with Augustine's ethica caritatis. In his commentary

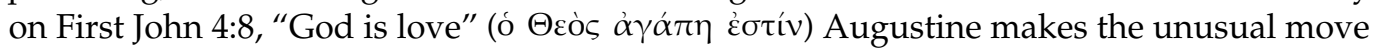
of flipping John's formulation "God is love" to its inverse "Love is God," a step too far for most commentators and theologians. But this move is a necessary one given Augustine's trinitarian doctrine and his Pneumatology. He offers three arguments in defense of the unusual formulation "Love is God": (1) Verse 7 says that we are "of God" because of the love within us. (2) We know that to act contrary to love is to disobey God. (3) If those who love are indwelt by the Spirit, then love must necessarily be the presence of God. ${ }^{45} \mathrm{He}$ strengthens this last claim by an appeal to Romans 5:5, "Hope does not fail because God's love has been poured into our hearts by the Holy Spirit." The love of God which is the Spirit is poured into our hearts by God who is the Spirit-the gift of God who God himself.

It is in this context that we find Augustine's maxim, "Love and do what you want." Once for all, then, a brief precept is given to you: Love, and do what you want. If you are silent, be silent with love; if you cry out, cry out with love; if you chastise, chastise with love; if you spare, spare with love. The root of love must be within; nothing but good can come forth from this root. ${ }^{46}$ 
And now we begin to see how human love which is so easily disordered and which is trapped within a fallen body, wretched and given to all kinds of lusts, can nevertheless function as the exclusive imperative which embodied all of moral theology. The love which Augustine has in mind is not fleshly or natural human affection, but the eternal love of God, the source and principle of the ordo amorum, the gift of God which is God himself, who has been poured into the Christian's heart and who wars against the flesh and its desires. We might paraphrase Augustine to say, "Be filled with the Spirit and do what you want." Or perhaps, as Paul puts it, "Work out your own salvation with fear and trembling, for it is God who works in you, both to will and to work for his good pleasure" (Phil. 2:12-13). ${ }^{47}$ Augustine's ethics, like his soteriology, is therefore radically God-centered and utterly dependent on grace.

\subsection{Pneumatological Love Ethics}

Ayres writes,

We cannot understand what it means for Augustine to call God love, and to call love God, without beginning to get an overall picture of the interrelationship between his theology of the Trinity, his theology of the incarnation, and his ecclesiology. 48

But we should add his ethics are also deeply imbedded in this interrelationship, and understanding what it means for Augustine to call God love, and to call Love God carries with it a distinctive approach to ethics both in theory and in practice.

Once we understand that love for Augustine is both the name and the fruit of the Spirit who indwells the Christian, what he means by "Love and do what you want" is suddenly much easier to understand. Indeed, Augustine goes further. For the one who loves (that is, the one who has the Spirit and is led by him), evil character becomes impossible. "The light shines in the darkness, and the darkness does not overcome it" (Jn. 1:5).

To have baptism is possible even for a bad man; to have prophecy is possible even for a bad man. To receive the sacrament of the body and blood of the Lord is possible even for a bad man. To have the name of Christ is possible even for a bad man. I say, to have all these sacraments is possible even for a bad man, but to have charity and to be a bad man is not possible. This then is the peculiar gift, this the Fountain that is singly one's own. To drink of this the Spirit of God exhorts you, to drink of Himself the Spirit of God exhorts you. ${ }^{49}$

We see in this quotation traces of a wide range of Augustine's thoughts on the topic. The reference to fountains and drink along with the language of "peculiar gift" recalls his commentary on John 4 and 7. We see also his ethical emphasis on the internal life of the Christian as the only true locus of good and evil. Both Ratzinger and Ayres have explored the connections between Augustine's Pneumatology and the Church, the sacraments, and Christian spirituality, but such connections with his ethical thought are sometimes overlooked. Therefore, I will close with a few brief observations about Augustine's Pneumatological ethics and some suggestions for further research.

First, the identification of the indwelling Holy Spirit with the ethical principle of love helps explain some of Augustine's more complex and controversial positions-for example his willingness to see Christians mete out punishment of evil, a key element of his teaching on war. Augustine points out that the loving God of Scripture is not afraid to rebuke, discipline, and destroy the evil in this world, and the Christian in whom God dwells by the Spirit will be called upon at times to express his love in just the same manner.

If any of you perchance wish to keep charity, brethren, above all things do not imagine it to be an abject and sluggish thing; nor that charity is to be preserved by a sort of gentleness, nay not gentleness, but tameness and listlessness. Not so is it preserved. Do not imagine that you then love your servant when you do not beat him, or that you then love your son when you give him not discipline, or 
that you then love your neighbor when you do not rebuke him: this is not charity, but mere feebleness. ${ }^{50}$

Augustine goes on to describe the "charity betokened by a dove" which descended at Christ's baptism. Why a dove? He asks. "The dove has no gall: yet with beak and wings she fights for her young; hers is a fierceness without bitterness." ${ }^{11}$ This "fierceness without gall" is the charity which the Doctor of the Church commends to his audience.

Secondly, Augustine's Pneumatological love ethics have an important role to play in contemporary virtue theory. Though he is not a systematic virtue theorist in the mold of Aquinas, his ad hoc approach to ethical questions, his deep commitment to moral principles along with his tendency to find unpredictable exceptions to those principles which can nevertheless be reasonably justified and compellingly presented, and his emphasis on becoming a new sort of person rather than simply making the right decision all run parallel to the themes of modern virtue ethics. While ethicists like Alasdair MacIntyre and Stanley Hauerwas have helped to reinvigorate interest in virtue theory and have connected it with the person of Jesus, both have an underdeveloped Pneumatology. ${ }^{52}$ But the ascendency of virtue ethics in contemporary moral theology demands a parallel increase in attention given to the Holy Spirit. Here Augustine has important insights to share, not least of which is his abiding claim that genuine moral transformation is dependent on the prevenient work of the Spirit as well as his indwelling and sanctifying activities that come later.

Finally, it would benefit us to ask about the ways in which Augustine's ethica caritatis helps inform our theology, in particular our doctrine of the Spirit. Ayres writes, "The temporal and bodily practice of love of neighbor is the process at the core of all our attempts to come to terms with the mystery of God's presence." ${ }^{\prime 53}$ That is, if we want to understand the person and work of the Spirit more fully, our best path may lie in caring for the poor, working for peace and the preservation of life in our communities, and disciplining our appetites so that they conform to Christian principles. These ethical practices may appear trite to those seeking to delve deeply into the study of esoteric realms of academic theology, but Augustine's collapsing of ethics and Pneumatology into a single category demonstrates that knowledge of God is impossible outside of love for God and love for neighbor. Here, as always, Augustine's invaluable contribution is to challenge our pride and humble our hearts so that they can become open to the work of the Spirit who seeks to make a home for God there.

Funding: This research received no external funding.

Conflicts of Interest: The author declares no conflict of interest.

\section{Notes}

(Augustine 2012, p. 11).

(Brown 1960, p. 432). For more on the significance of weeping in Augustine's theology see: (Werpehowski 1991, pp. 175-91) and (Griffiths 2011, pp. 19-28).

3 Nowhere is this more clear than in the famous story from Confessions in which he describes stealing pears. The allusions to the Garden of Eden are meant to show not that he was especially wicked, but that he was typical of humanity-that Adam's story is the story of us all. Confessions, 2, 9-14.

4 (Augustine 1996, p. 20). For examples of how this "use" vs. "enjoy" polarity plays out in Augustinian ethics see (McGowan 2010, pp. 89-99; Dupont 2006, pp. 89-93; Dodaro 2015, pp. 511-26).

5 (Augustine 2008, 7.8).

6 (Johnson 2000, p. 654).

7 (Greenman 2007).

8 Of course, this in no way implies that the Sermon on the Mount was irrelevant for Augustine.

9 (O’Donovan 2006, p. 4).

$10 \quad$ (Augustine 1990, 1.15.8).

11 (Cary 2013). 
(Augustine 2013), This is a theme explored in a variety of Augustine's works but is most clearly and concisely presented in his Enchiridion on Faith, Hope, and Love 3.9-11 and 4.12-15. See also Confessions 7.7; 16.22; City of God, 11.9; etc. For a robust discussion of the Augustinian view of evil and the will, see (Burns 1988, pp. 9-28); (Evans 1990), and especially, (Willows 2014, pp. 255-69). (Pratt 1903, p. 224), It is the will, therefore, and the will alone, that is essentially evil [for Augustine]. The thing toward which the evil will turns is neither evil nor good. Nothing is evil but the evil will." (Augustine 1925, p. 52).

Thus, the $u t i / f r u i$ distinction is primarily about the transcendent nature of God and not about any comprehensive ethical system. When Augustine says that people are to be "used", he means by this something radically different than what Kant has in mind in his categorical imperative prohibiting treating people as means rather than ends. For a fuller treatment of this difference and of the uti/frui distinction in general see (Naldini and Hill O. P. 1990, pp. 17-19).

Augustine, Homilies on First John, 2.11, emphasis mine.

In both De Doctrina and Homilies on First John, Augustine identifies temporality as the key failing of the world. God is to be enjoyed because he is the eternal one. In Homilies, Augustine makes this point powerfully in his discussion of the Incarnation: "Will you love the things of time, and pass away with time; or not love the world, and live to eternity with God? The river of temporal things hurries one along; but like a tree sprung up beside the river is our Lord Jesus Christ. He assumed flesh, died, rose again, ascended into heaven. It was his will to plant himself, in a manner, beside the river of the things of time. Are you rushing down the stream to the headlong deep? Hold fast the tree. Is love of the world whirling you on? Hold fast Christ. For you he became temporal, that you might become eternal." Homilies on First John 2.10. Augustine, Homilies 2.12. Augustine, De Trinitate 8.12. Augustine, De Trinitate, 15.4. The comment about "true love" comes in the opening lines of book 8 . Augustine, De Trinitate, 8.13.

De Trinitate, $15.28,31$.

(Ayres 1996, p. 484).

(Ratzinger 1998, p. 326).

(Ratzinger 1998, p. 326).

De Trinitate, 15.47-48. For an excellent description of the filioque in Christian theology and history see (Siecienski 2010).

See Hilary's De Trinitate 2.1 and 2.3. For an extended treatment of this important element of Augustinian Pneumatology, see ( Smith 2011, p. 121).

Ratzinger, 330. Ratzinger points out that these passages join Augustine's Christology with his Pneumatology; Christ is the well or spring and the Spirit is the water. "The well of the Spirit is the crucified Christ. From him each Christian becomes a well of the Spirit." For an excellent exegetical treatment of the passages in question and their attendant Pneumatology, see (Allison 1986, pp. 143-57).

This distinction is vital for Augustinians like Ratzinger who wish to rebut accusations that Augustine's trinitarian doctrine smacks of modalism. For an example of one such critique see (Myendorff 1979, pp. 186-87).

Augustine, De Trinitate, 5.14 .

Thomas Aquinas, Summa Theologiae, 2A.65.5

(David Vincent Menconi 2014, p. 222).

Samson is the chief example of such a pattern. (Judges 13-16) But the same can be said of all the judges of Israel and her first king. (Ratzinger 1998, pp. 328-29).

(Ratzinger 1998, pp. 332-33). It should be noted that much of the primary source material Ratzinger draws on, including the Homilies on First John, was produced during the conflict with the Donatists and therefore has particularly strong ecclesiological emphases.

"But the Helper, the Holy Spirit, whom the Father will send in my name, he will teach you all things ... "

(Harvey 1951, pp. 19-22). The divine grace in question can be identified as the gift of the Holy Spirit.

(Augustine 2012, 10.5.7).

This illuminationist view of knowledge is present in early works such as De Magistro, but deepend and became more sophisticated over the course of Augustine's career. 


\section{References}

Allison, Dale C. 1986. The Living Water: John 4:10-14, 6:35c, and 7:37-39. Vladamir's Theological Quarterly 2: 143-57.

Augustine. 1925. On the Spirit and the Letter. New York and London: Society for Promoting Christian Knowledge.

Augustine. 1990. The Catholic Way of Life and the Manichean Way of Life (De Moribus ecclesiae Catholicae et De Moribus Manichaeorum). Hyde Park: New City Press.

Augustine. 1996. Teaching Christianity/De Doctrina Christiana. New York: New City Press.

Augustine. 2008. Homilies on the First Epistle of John. New York: New City Press.

Augustine. 2012. The Confessions: Study edition, (The Works of Saint Augustine: A Translation for the 21st Century), 2nd ed. Edited by John E. Rotelle. New York: New City Press.

Augustine. 2013. City of God (De Civitate Dei). Translated by William Babcock. Hyde Park: New City Press.

Ayres, Lewis. 1996. Augustine on God as Love and Love as God. Pro Ecclesia 5: 484. [CrossRef]

Brown, Peter. 1960. Augustine of Hippo: A Biography. Los Angeles: University of California Press, p. 432.

Burns, J. Patout. 1988. Augustine on the Origin and Progress of Evi. Journal of Religius Ethics 16: 9-28.

Cary, Phillip. 2013. Evil, Free Will, Original Sin, and Predestination. In Augustine, Philosopher and Saint. Chantilly: The Great Courses. Chappell, Timothy. 2014. Augustine's Ethics. In The Cambridge Companion to Augustine, 2nd ed. Edited by David Vincent Meconi S. J. and Eleonore Stump. Cambridge: Cambridge University Press.

Dodaro, Robert. 2015. Augustine on enjoying One's Neighbor: Uti-Frui Once Again. Lateranum 80: 511-26.

Dupont, Anthony. 2006. To Use or Enjoy Humans? Uti and Frui in Augustine. Paper Presented at 14th International Conference on Patristic Studies, Oxford, UK, August 8.

Evans, Gillian R. 1990. Augustine on Evil. Cambridge: Cambridge University Press.

Greenman, Jeffrey P. 2007. The Sermon on the Mount Through the Centuries. Edited by Timothy Larsen and Stephen R. Spencer. Grand Rapids: Brazos. Griffiths, Paul J. 2011. Tears and Weeping: An Augustinian View. Faith and Philosophy 28: 19-28. [CrossRef]

Harvey, John F. 1951. Moral Theology of the Confessions of Saint Augustine. Washington, DC: CUA Press.

Hauerwas, Stanley. 2015. How the Spirit Works. In The Work of Theology. Grand Rapids: Eerdmans.

Johnson, Luke Timothy. 2000. The Sermon on the Mount. In The Oxford Companion to Christian Thought. Edited by Adrian Hastings. Oxford: Oxford University Press.

McGowan, Andrew. 2010. To Use and to Enjoy: Augustine and Ecology. St. Mark's Review. Available online: https://anglican.org.au/ wp-content/uploads/2019/05/To-Use-and-Enjoy-Augustine-and-Ecology-Andrew-McGowan.pdf (accessed on 20 July 2021).

Menconi, David Vincent. 2014. Augustine's Doctrine of Deification in The Cambridge Companion to Augustine. Cambridge: Cambridge University Press.

Myendorff, John. 1979. Byzantine Theology: Historical Trends and Doctrinal Themes. NewYork: Fordham University Press.

Naldini, Mario, and Edmund Hill O. P. 1990. Structure and Pastoral Theology of Teaching Christianity. Translated by Edmund Hill O. P. Introduction to Teaching Christianity. Hyde Park: New City Press.

O'Donovan, Oliver. 2006. The Problem of Self-Love in St. Augustine. Eugene: Wipf and Stock.

Pratt, James Bissett. 1903. The Ethics of St. Augustine. International Journal of Ethics 13: 224. [CrossRef]

Ratzinger, Cardinal Joseph. 1998. The Holy Spirit as Communio: Concerning the Relationship of Pneumatology and Spirituality in Augustine. communio-spokane then washington. Available online: https://www.communio-icr.com/articles/view/the-holy-spiritas-communio (accessed on 28 July 2021).

Siecienski, A.E. 2010. The Filioque: History of a Doctrinal Controversy. Oxford: OUP.

Smith, J. Warren. 2011. The Trinity in the Fourth-Century Fathers. In The Oxford Handbook of the Trinity. Edited by O. P. Gilles Meery and Matthew Levering. Oxford: OUP.

Werpehowski, William. 1991. Weeping at the Death of Dido: Sorrow, Virtue, and Augustine's 'Confessions'. The Journal of Religious Ethics 19: 175-91.

Willows, Adam M. 2014. Augustine, the Origin of Evil and the Mystery of Free Will. Religions Studies 50: 255-69. [CrossRef] 